\title{
Bovine mastitis caused by rapid-growth environmental mycobacteria
}

\author{
L. Cvetnić, S. Špičić, G. Kompes, B. Habrun, V. Katalinić-Janković, \\ M. Cvetnić, M. Zdelar-Tuk, I. Reil, S. Duvnjak, Ž. Cvetnić i M. Benić*
}

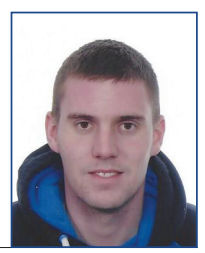

\section{Abstract}

Rapid-growth mycobacteria were isolated from two cases of cow mastitis with similar clinical appearance and within a narrow time frame. Mycobacteria were isolated on blood esculine agar. The isolated mycobacteria were Gram stained, Ziehl-Nielsen stained and tested for growth at $25^{\circ} \mathrm{C}, 37^{\circ} \mathrm{C}$ and $42^{\circ} \mathrm{C}$, iron uptake, growth on LöwensteinJensen (LJ) agar with and without $5 \% \mathrm{NaCl}$, arylsulphatase ( 3 days), tween 80 hydrolysis, tellurite reduction, nitrate reductase and niacin synthesis. Molecular identification was performed using the Mycobacteria GenoType $\mathrm{CM}$ and AS tests (Hain Diagnostika, Nehren, Germany). One isolate was additionally sequenced for the $h s p 65, r p o B, 16 \mathrm{~S}$ rRNA gene sequence and transcribed spacer sequence (ITS) DNA. Susceptibility testing of isolates was performed on the Sensititre Rapmycol plate (TREK Diagnostic Systems Ltd.) for trimethoprim/sulfamethoxasole, linezolid, ciprofloxacin, imipenem, moxifloxacin, cefepime, cefoxitin, amoxicillin/clavulanic acid, amikacin, ceftriaxone, doxycycline, minocycline, tigecycline, tobramycine and clarythromycine. Gram-positive acid-resistant rods were observed in stained smears. Both strains grew at $25^{\circ} \mathrm{C}, 37^{\circ} \mathrm{C}$ and $42^{\circ} \mathrm{C}$ on $\mathrm{LJ}$ medium, and on LJ medium containing $5 \%$ $\mathrm{NaCl}$. The conventional biochemical tests for iron uptake, arylsulphatase (3 days), Tween 80 hydrolysis, tellurite reduction and nitrate reductase were positive, while the niacin test was negative. Both isolates were identified by the GenoType Mycobacterium $\mathrm{CM}$ as Mycobacterium fortuitum II/ Mycobacterium mageritense, while application of the GenoType Mycobacterium AS kit identified both isolates as belonging to the species Mycobacterium smegmatis. Analysis of the isolate sequences (strain DS) for 16S ribosomal RNA confirmed a $100 \%$ identical result with Mycobacterium smegmatis strain INHR2. According to the CLSI criteria, both strains were sensitive to sulfametoxazole/trimethoprim, linezolid, doxicycline, amikacin and tobramycin. The strains differed in their sensitivity to cefoxitim, and both strains were resistant to clarithromycin. There was a strong difference between the isolates in sensitivity toward cefoxitime and tigecycline.

Key words: mycobacterium; mastitis; cow

Luka CVETNIĆ, DVM, PhD, Silvio ŠPIČIĆ, DVM, PhD, Gordan KOMPES, DVM, PhD, Boris HABRUN, DVM, PhD, Croatian Veterinary Institute, Zagreb, Croatia; Vera KATALINIĆ-JANKOVIĆ, dr. med., Croatian Institute of Public Health, Croatia; Marija CVETNIĆ, DVM, Assistant, Faculty of Veterinary Medicine University of Zagreb, Zagreb, Croatia; Maja ZDELAR TUK, DVM, PhD, Irena REIL, DVM, PhD, Sanja DUVNJAK, BSc, PhD, Croatian Veterinary Institute, Zagreb, Croatia; Željko CVETNIĆ, DVM, Academician, Croatian Veterinary Institute, Veterinary Department Križevci, Croatia; Miroslav BENIĆ*, DVM, PhD, Croatian Veterinary Institute Zagreb, Croatia, (Corresponding author: benic@veinst.hr) 


\section{Introduction}

Mastitis in dairy cows is considered a cause of greatest losses in dairy production, and it most commonly is caused by bacteria (Cvetnić et al., 2016; Turk et al., 2017; Benić et al., 2018; Mimoune et al., 2021; Lamari et al., 2021). The contemporary literature lists over 135 different causative agents of mastitis (Watts, 1988). Some udder pathogens are important as potential causes of infections in humans or food-borne infections and intoxications (Juhász-Kaszanyitzky et al., 2007; Scallan et al., 2011; Burović, 2020; Saidi et al., 2021; Cvetnić et al., 2021; Knežević et al., 2021).

Mycobacteria are gram-positive aerobic bacteria belonging to the family Mycobacteriaceae. In terms of the time needed for growth on nutritive agar, they are differentiated into slow and rapidgrowth species. Slow-growth species include the members of the $M$. tuberculosis complex and other slow growing species. Colonies of slow-growth species on solid agar appear after seven days or longer. Rapid-growth species appear on agar in less than seven days (Han et al., 2007). According to the Runyon classification, rapid-growth species are included in category 4 . They are often isolated in microbiology laboratories, and are associated with numerous infections in humans (Esteban et al., 2007). The clinically most significant, unpigmented, rapid-growth mycobacteria are divided into three groups: $M$. fortuitum group, $M$. chelonae/abscessus group and M. smegmatis group (Brown-Elliott and Wallace, 2002).

To date, the Mycobacterium fortuitum group has been isolated from water, water supply systems and various types of soil (Franco et al., 2013). This group includes three taxa: M. fortuitum, M. peregrinum and one unnamed taxon. It is most often a member of the non-tuberculosis mycobacteria isolated from the mammary glands of dairy cows. Until the 1970s, it was considered a saprophyte; however, its pathogenicity for humans has since been demonstrated many times (Hand and Sanford, 1970; Dreisin et al., 1976; Nolan et al., 1991; Rotman et al., 1993). The $M$. fortuitum group causes localised post-traumatic infections, infections from catheter use, and infections of surgical wounds, particularly following mammoplastic and heart operations (Brown-Elliott and Wallace, 2002). M. mageritense is included in an unnamed complex that includes several other species (M. houstonense, M. septicum and $M$. bonickei). All have been associated with human disease. The species was first described in 1997 (Domenech et al., 1997) when it was isolated from human sputum. It is assessed that $75 \%$ of infections caused by this complex are associated with infections of the skin, soft tissues or bone (Brown-Elliott and Wallace, 2002).

The $M$. chelonaelabscessus complex includes a number of species, including $M$. chelonae, $M$. abscessus and $M$. immunogenum. Infections in humans manifest as chronic lung disorders, localised cellulitis, osteomyelitis and arthritis (Lee et al., 2015).

The $M$. smegmatis group includes multiple members. This group differs from the $M$. fortuitum and $M$. chelonael abscessus groups due to the lack of sensitivity to new macrolids. It was first isolated and described in 1885 . Until recently, members of the group were considered saprophytes without any clinical significance. The first described case in humans caused by a member of this group was reported in 1986, when it was isolated from a patient with lung disease. Following this, this group was associated with cases of cellulitis, localised abscesses and osteomyelitis following traumatic injuries. Additionally, sporadic cases of complications have been reported following surgical procedures, such as catheterisation, pacemaker implants and 
plastic surgery procedures (Wallace et al., 1988, 1989; Xu et al., 2013).

The aim of this research was to identify strains of mycobacteria isolated from two bovine mastitis cases and to examine their susceptibility to selected antimicrobials.

\section{Material and methods}

Two samples of dairy gland secretions were delivered to the laboratory at onemonth intervals. Samples originated from geographically remote farms without any mutual contact. In both cases, the medical history records coincided. Samples were taken from Simmental breed dairy cows, ages 6 and 7 years, at about 5 months gravidity. Cows were kept indoors and milked mechanically. The infected cows did not display any clinical signs. In both cows, the infected udder was predominantly harder than the remainder of the gland, with an increased somatic cell count in milk. The sample from the infected udder was delivered to the diagnostic laboratory for testing.

\section{Bacteriological testing}

Milk samples were inoculated on esculin-blood agar and incubated at a temperature of $37^{\circ} \mathrm{C}$. The growth of microbial cultures was examined at 24hour intervals. Cultures were Gramstained and Ziehl-Nielsen stained. Both isolates were typed biochemically and using molecular methods. The prescribed procedure of NTM species in Croatia is conducted using the determination of growth properties and biochemical properties of the strain (growth at 25, 37 and $42^{\circ} \mathrm{C}$, ability to produce pigment, semi-quantitative catalase test, Tween 80 hydrolysis, arylsulfatase test ( 3 and 14 days), thermostable catalysis $(\mathrm{pH}$ $\left.7,68^{\circ} \mathrm{C}\right)$, pyrazine amidase (4 and 7 days), urease, nitrate reduction and colony morphology). Subcultivation was performed using the BACTEC
MGIT culture system (Becton Dickinson, Maryland, USA) and by inoculation on Löwenstein-Jensen agar in duplicate.

\section{Molecular identification}

\section{DNA isolation}

Mycobacterial isolates were prepared on solid nutritive agar. Bacterial culture was suspended in $1 \mathrm{~mL}$ distilled water. Bacterial DNA was extracted by boiling at $100^{\circ} \mathrm{C}$ for 15 minutes. Samples were centrifuged at $13400 \mathrm{~g}$ during 2 minutes, and the obtained supernatant was used for further analysis.

\section{Species identification}

Identification was performed using the Mycobacteria GenoType CM and AS tests (Hain Diagnostika, Nehren, Germany). The system is intended for the identification of the M. tuberculosis complex and for the 40 most common NTM species cultivated from the species.

\section{Geno-typing}

The mycobacteria test was performed according to manufacturer's recommendations (Hain Germany). The procedure included replication of the PCR product, hybridisation of the PCR product and detection of bound PCR products. For more precise identification of the mycobacterial species for the strain DS (Dugo Selo), additional comparisons were made of the sequences hsp65, rpoB, $16 S$ rRNA gene and transcribed spacer sequence (ITS) DNA, using gene fragments with the forward and reverse primers:

Tb11 (5'-ACC AAC GAT GGT GTG

TCC-3') and

Tb12 (5'-CTT GTC GAA CCG CAT ACC

CT-3' (Telenti et al., 1993; Adékambi and Drancourt, 2004)

Myco-F

(5'-GGCAAGGTCACCCCGAAGGG-3') and

Myco-R

(5'-AGCGGCTGCTGGGTGATCATC-3'); $16 \mathrm{MycF}$ (59-CGTGCTTAACA- 
CATGCAAGTCG-39) and

16MycR (59-GTGAGATTTCACGAACA-

ACGC-39) (Devulder et al., 2005),

Ec16S.1390b (5'-TTG TAC ACA CCG

CCC GTC A-3') and

Mb23S.44n (5'-TCT CGA TGC CAA

GGC ATC CAC C-3').

Sequences were analysed against public gene sequence repositories at the GenBank National Centre for Biotechnology Information. The sequence comparison with the reference strains from GenBank was performed using the algorithm BLAST.

\section{Antimicrobial Susceptibility testing}

Susceptibility testing of isolates was made by Sensititre Rapmycoi plate (TREK Diagnostic Systems Ltd.), in accordance with the Sensititre protocol. The plate was dosed with antimicrobial agents at appropriate dilutions: trimethoprim/sulfamethoxasole 0.25/4.75-8/152, linezolid 1-32, ciprofloxacin 0.12-4, imipenem 2-64, moxifloxacin $0.25-8$, cefepime 1-32, cefoxitin 4-128, amoxicillin/clavulanic acid 2/1-64/32, amikacin 1-64, ceftriaxone 4-64, doxycycline 0.12-16, minocycline $1-8$, tigecycline $0.015-4$, tobramycin $1-16$, clarythromycin 0.06-16.

The mycobacterium culture was emulsified in demineralized water (Api Suspension Medium, $5 \mathrm{~mL}$, bioMérieux SA) and adjusted to a $0.5 \mathrm{McF}$ arland (Densimat, bioMérieux). A total of 50 $\mu \mathrm{L}$ of suspension was transferred into the cation tube of the adjusted MuellerHinton broth with TES (Thermo Scientific, Remel Inc.). Then $100 \mu \mathrm{L}$ of suspension was transferred to each well. Plates were incubated aerobically at $30^{\circ} \mathrm{C}$ in a non- $\mathrm{CO}_{2}$ incubator for 96 hours. Staphylococcus aureus ATCC 29213 was used for quality control. The result was read manually by visual reading of growth with a mirror viewer and interpreted according to CLSI M24-A2 (2).

\section{Results}

\section{Bacteriological testing}

The growth of pure cultures of bacterial colonies was observed after 72 hours of incubation on esculin-blood agar. The strains are designated as DS (Dugo Selo) and BJ (Bjelovar) based on the place of origin. In gram-stained culture smears, gram-positive rods were visible. Smears were stained with Ziehl-Nielsen stain, following which acid-resistant rods were observed.

\section{Biochemical properties}

Table 1. Biochemical/culture properties of the isolates DS and BJ

\begin{tabular}{|l|l|l|}
\hline Test/property & DS & \multicolumn{1}{|c|}{ BJ } \\
\hline Growth at $25^{\circ} \mathrm{C}$ & positive & positive \\
\hline Growth at $37^{\circ} \mathrm{C}$ & positive & positive \\
\hline Growth at $42^{\circ} \mathrm{C}$ & positive & positive \\
\hline Iron uptake & positive & positive \\
\hline $\begin{array}{l}\text { Growing on LJ } \\
\text { with } 5 \% \mathrm{NaCl}\end{array}$ & positive & positive \\
\hline $\begin{array}{l}\text { Arylsulphatase } \\
\text { (3 days) }\end{array}$ & positive & positive \\
\hline Tween 80 hydrolysis & positive & positive \\
\hline Tellurite reduction & positive & positive \\
\hline Nitrate reductase & positive & positive \\
\hline Niacin & negative & negative \\
\hline
\end{tabular}

The cultures grew at $25^{\circ} \mathrm{C}, 37^{\circ} \mathrm{C}$ and $42^{\circ} \mathrm{C}$ on LJ medium, and on LJ medium containing $5 \% \mathrm{NaCl}$. The conventional biochemical tests for iron uptake, arylsulphatase (3 days), Tween 80 hydrolysis, tellurite reduction and nitrate reductase were positive, while niacin was negative. (Table 1).

Both isolates (BJ and DS) were identified by the GenoType Mycobacterium CM as Mycobacterium fortuitum II/ Mycobacterium mageritense, 
Table 2. CLSI interpretative criteria and observed MIC break-points of two strains

\begin{tabular}{|l|c|c|c|c|c|}
\hline \multirow{2}{*}{ Agent } & \multicolumn{3}{|c|}{ CLSI criteria } & \multicolumn{2}{c|}{ Observed } \\
\cline { 2 - 7 } & $\mathbf{S}$ & $\mathbf{I}$ & $\mathbf{R}$ & Strain BJ & Strain DS \\
\hline Sulfametoxazole/trimethoprim & $\leq 2 / 38$ & - & $\geq 4 / 76$ & $\geq 0.254 / 4.75$ & $\geq 0.254 / 4.75$ \\
\hline Linezolid & $\leq 8$ & 16 & $\geq 32$ & $\geq 2$ & $\geq 2$ \\
\hline Ciprofloxacin & $\leq 1$ & 2 & 4 & $\geq 0.5$ & $\geq 0.5$ \\
\hline Imipenem & $\leq 4$ & $8-16$ & $\geq 32$ & $\geq 4$ & $\geq 4$ \\
\hline Moxifloxacin & $\leq 1$ & 2 & $\geq 4$ & $\geq 0.25$ & $\geq 0.25$ \\
\hline Cefepime & - & - & - & $r$ & $r$ \\
\hline Cefoxitim & $\leq 16$ & $32-64$ & 128 & $\geq 32$ & $\geq 16$ \\
\hline Amoxicillin with clavulanic acid & - & - & - & $\geq 32 / 16$ & $\geq 32 / 16$ \\
\hline Amikacin & $\leq 16$ & 32 & $\geq 64$ & $\geq 1$ & $\geq 1$ \\
\hline Ceftriaxone & - & - & - & $r$ & $r$ \\
\hline Doxycycline & $\leq 1$ & $2-4$ & $\geq 8$ & $\geq 0.12$ & $\geq 0.12$ \\
\hline Minocycline & - & - & - & $\geq 1$ & $\geq 1$ \\
\hline Tigecycline & - & - & - & $\geq 0.12$ & $\geq 0.03$ \\
\hline Tobramycin & $\leq 2$ & 4 & $\geq 8$ & $\geq 1$ & $\geq 1$ \\
\hline Clarithromycin & $\leq 2$ & 4 & $\geq 8$ & $r$ & $\geq 8$ \\
\hline
\end{tabular}

and application of the GenoType Mycobacterium AS kit identified both isolates as belonging to the species Mycobacterium smegmatis.

Analysis of the isolate sequences (strain DS) for $16 S$ ribosomal RNA confirmed a $100 \%$ identical result with Mycobacterium smegmatis strain INHR2, complete genome, Sequence ID: CP009496.1 and a high similarity of $99 \%$ for the ITS sequence with Mycobacterium smegmatis strain INHR2, complete genome, Sequence ID: CP009496.1, of the rpoB gene with Mycobacterium smegmatis genome strain NCTC8159, GenBank: LN831039.1 and of the hsp65 gene for $M$. smegmatis strain RGTB229 $65 \mathrm{kDa}$ heat shock protein (hsp65) gene, partial cds, Sequence ID: HM454229.1.

According to the CLSI criteria for the interpretation of sensitivity of rapid-growth mycobacteria, both strains are sensitive to sulfametoxazole/ trimethoprim, linezolid, doxycycline, amikacin and tobramycin. The strains differ in their sensitivity to cefoxitim. (Table 2).

\section{Discussion}

The pathogenicity of $M$. fortuitum and M. smegmatis was proven following trial infections in fish (Talaat et al., 1999) and in cats (Brown et al., 1999). Infections in cats most often manifest as panniculitis, and arise from injuries during fights with other cats (Malik et al., 2000; Gunn-Moore et al., 2013).

Though literature reports associate mastitisindairy cows with mycobacteria, there are few described cases and published reports. Richardson (1970) described multiple cases of mastitis in dairy cows caused by M. smegmatis and untypable mycobacteria, by associating 
the infections with the application of medicine to the udder. Wetzstein and Greenfield (1992) described the appearance of mycobacterial mastitis in cows in British Columbia, Canada, and stated that of the 18 isolates, 17 were identified as $M$. fortuitum, and one as M. chelonei. Schultze and Brasso (1987) described and identified 20 isolates of mycobacteria isolated from the milk of cows with mastitis, and all isolates were identified as M. smegmatis. Thomson et al. (1988) described the appearance of acute clinical mastitis caused by $M$. smegmatis after antibiotic therapy of cows. Mycobacteria were also isolated from milk samples collected from collecting stations (Franco et al., 2013).

Both isolates of the mycobacteria described in this study originated from the mammary glands of dairy cows containing an increased number of somatic cells and displaying an altered consistency of the tissue in the affected udder quarter. Since the medical history of the infected cows did not list prior cases of mastitis, it is not possible to determine whether mycobacteria were the primary cause of the mastitis, or whether the infection arose following the improper application of medicine. The fact that one of the first signs of infection was a change in consistency of mammary gland tissue indicates that the primary cause of the mastitis could be mycobacteria.

The results of genetic identification of both isolates in this study were similar. The isolates were identified using the GenoType Mycobacteria $\mathrm{CM}$ test as Mycobacterium fortuitum II/ Mycobacterium mageritense and with the GenoType Mycobacteria AS kit as the species M. smegmatis. Since there is a possibility of overlap between individual species in the identification of species using the GenoType Mycobacteria test, and due to the description of new species in recent years, gene fragments were also analysed to obtain precise identification. The results of testing on gene fragments indicated the highest overlap of the analysed isolates with the species $M$. smegmatis, which was further supported by the established insensitivity to macrolids (clarithromycin). The fundamental biochemical properties of the isolated mycobacteria are similar to the properties of rapid-growth mycobacteria described elsewhere (Nasr Esfahani et al., 2012).

There are very few reports in the literature on the sensitivity of mycobacteria isolated from animals. Infections caused by members of the Mycobacterium tuberculosis complex are notified to competent authorities and the affected animals are removed from further breeding. Infections by rapidgrowth mycobacteria are not subject to mandatory notification, and mammary gland infections in cows caused by mycobacteria are generally not treated. Despite this, sensitivity data towards antimicrobial compounds isolated from cows are useful to allow for the better knowledge of bacterial resistance dynamics, and the possible role of mycobacteria in the transmission of resistance genes. The $M$. smegmatis and M. fortuitum third biovariant is generally insensitive to macrolide therapy, including clarithromycin which has a dominant role in antimicrobial therapy for RGM infections (Brown-Elliott and Wallace, 2002).

The isolated strains in this study were not completely identical with regard to sensitivity towards antimicrobial compounds. According to the CLSI criteria for the interpretation of sensitivity of rapid growing mycobacteria, the BJ strain is moderately sensitive to cefoxitim, while the DS strain is sensitive to this antibiotic. Both strains are resistant to clarithromycin, even though the MIC differs. The difference between the 
isolates in the sensitivity to tigecycline was evident, at $0.03 \mu \mathrm{g} / \mathrm{mL}$ (BJ) and 0.12 $\mu \mathrm{g} / \mathrm{mL}$ (DS).

\section{Conclusion}

Sporadic infections of the mammary glands caused by mycobacteria are evidence of the need for ongoing monitoring of mammary gland health. Both species described in this study may cause infection in humans, but also represent an infection model for other pathogenic species. Despite the fact that infections caused by mycobacteria are not treated in animals, there is an obvious resistance towards certain antimicrobial compounds. Since antibiotics are used to treat infections caused by other bacterial species, mycobacteria likely come into contact with antimicrobial compounds by activating their own resistance mechanisms. In all cases of mastitis in cows with unsuccessful antimicrobial treatment in the medical history or negative bacteriological tests for the usual bacterial causative agents, Mycobacteriae should be suspected as the possible causative agent.

\section{References}

1. ADEKAMBI, T. and M. DRANCOURT (2004): Dissection of phylogenetic relationships among 19 rapidly growing Mycobacterium species by 16S rRNA, hsp65, sodA, recA and rpoB gene sequencing. Int. J. Syst. Evol. Microbiol. 54, 20952105. 10.1099/ijs.0.63094-0

2. BENIĆ, M., N. MAĆEŠIĆ, L. CVETNIĆ, B. HABRUN, Ž. CVETNIĆ, R. TURK, D. ĐURIČIĆ, M. LOJKIĆ, V. DOBRANIĆ, H. VALPOTIĆ, J. GRIZELJ, D. GRAČNER, J. GRBAVAC and M. SAMARDŽIJA (2018): Bovine mastitis: a persistent and evolving problem requiring novel approaches for its control - a review. Vet. arhiv 88, 535-557. 10.24099/vet.arhiv.0116

3. BROWN, B. A., B. SPRINGER, V. A. STEINGRUBE, R. W. WILSON, G. E. PFYFFER, M. J. GARCIA, M C. MENENDEZ, B. RODRIGUEZ-SALGADO, K. C. JOST Jr, S. H. CHIU, G. O. ONYI, E. C. BÖTTGER and R. J. WALLACE Jr (1999): Mycobacterium wolinskyi sp. nov. and Mycobacterium goodii sp. nov., two new rapidly growing species related to Mycobacterium smegmatis and associated with human wound infections: a cooperative study from the International Working Group on Mycobacterial. Int. J. Syst. Bacteriol. 49, 1493-1511. 10.1099/00207713-49-4-1493

4. BROWN-ELLIOTT, B. A. and R. J. WALLACE (2002): Clinical and taxonomic status of pathogenic nonpigmented or late-pigmenting rapidly growing mycobacteria. Clin. Microbiol. Rev. 15, 716-746. 10.1128/CMR.15.4.716-746.2002

5. BUROVIĆ, J. (2020): Isolation of bovine clinical mastitis bacterial pathogens and their antimicrobial susceptibility in the Zenica region in 2017. Vet. stn. 51, 47-52. (In Croatian). 10.46419/vs.51.1.5

6. CVETNIĆ, L., M. SAMARDŽIJA, B. HABRUN, G. KOMPES and M. BENIĆ (2016): Microbiological monitoring of mastitis pathogens in the control of udder health in dairy cows. Slov. Vet. Res. 53, 131-140.

7. CVETNIĆ, L., M. SAMARDŽIJA, S. DUVNJAK, B. HABRUN, M. CVETNIĆ, V. JAKI TKALEC, D. ĐURIČIĆ and M. BENIĆ (2021): Multi Locus Sequence Typing and spa Typing of Staphylococcus aureus Isolated from the Milk of Cows with Subclinical Mastitis in Croatia. Microorganisms 9, 725. 10.3390/microorganisms 9040725

8. DEVULDER, G., M. PPEROUSE DE MONTCLOS and J. P. FLANDROIS (2005): A multigene approach to phylogenetic analysis using the genus Mycobacterium as a model. Int. J. Syst. Evol. Microbiol. 55, 293-302. 10.1099/ijs.0.63222-0

9. DOMENECH, P., S. JIMENEZ, M. C. MENENDEZ, T. J. BULL, S. SAMPER, A. MANRIQUE and M J. GARCIA (1997): Mycobacterium mageritense sp. nov. Int. J. Syst. Bacteriol. 2, 535-540 10.1099/00207713-47-2-535

10. DREISIN, R. B., C. SCOGGIN and P. T. DAVIDSON (1976): The pathogenicity of Mycobacterium fortuitum and Mycobacterium chelonei in man: A report of seven cases. Tubercle 57, 49. 10.1016/00413879(76) 90017-9

11. ESTEBAN, J., R. FERNANDEZ ROBLA, J. I. GARCIA CIA, N. ZAMORA and A. ORTIZ (2007): Clinical significance and epidemiology of nonpigmented rapidly growing mycobacteria in a university hospital. J. Infect. 54, 135-145. 10.1016/j jinf.2006.02.017

12. FRANCO, M. M. J., A. C. PAES, M. GARCIA RIBEIRO, J. C. DE FIGUEIREDO PANTOJA, A C. BARRETO SANTOS, M. MIYATA, C. QUEICO FUJIMURA LEITE, R. GARCIA MOTTA and F. J. PAGANINI LISTONI (2013): Occurrence of mycobacteria in bovine milk samples from both individual and collective bulk tanks at farms and informal markets in the southeast region of Sao Paulo, Brazil. BMC Vet. Res. 9, 1-8. 10.1186/17466148-9-85

13. GUNN-MOORE, D. A., C. GAUNT and D. J. SHAW (2013): Incidence of Mycobacterial Infections in Cats in Great Britain: Estimate from Feline Tissue Samples Submitted to Diagnostic Laboratories. 
Transb. Emerging Dis. 60, 338-344. 10.1111/j.18651682.2012.01352.x

14. HAN, X. Y., I. DE and K. L. JACOBSON (2007): Rapidly Growing Mycobacteria Clinical and Microbiologic Studies of 115 Cases. Am. J. Clin. Pathol. 128, 612-621. 10.1309/1KB2GKYT1BUEYLB5

15. HAND, W. L. and J. P. SANFORD (1970): Mycobacterium fortuitum - A human pathogen. Ann. Intern. Med. 73, 931. 10.7326/0003-4819-73-6-971

16. JUHÁSZ-KASZANYTZKY, É., S. JANOSI, P. SOMOGYI, Á. DAN, L. VAN DER GRAAFVAN BLOOIS, E. VAN DUIJKEREN and J. A. WAGENAAR (2007): MRSA transmission between cows and humans. Emerg. Infect. Dis. 13, 630-632. 10.3201/eid1304.060833

17. KNEŽEVIĆ, K., V. DOBRANIĆ, D. ĐURIČIĆ, M. SAMARDŽIJA, M. BENIĆ, I. GETZ, M. EFENDIĆ, L. CVETNIĆ, J. ŠAVORIĆ, I. BUTKOVIĆ, M. CVETNIĆ, M. MAZIĆ, N. MAĆEŠIĆ (2021): Use of somatic cell count in the diagnosis of mastitis and its impacts on milk quality. Vet. stn. 52, 751-764. (In Croatian). 10.46419/vs.52.6.11

18. LAMARI, I., N. MIMOUNE and D. KHELEF (2021): Effect of feed additive supplementation on bovine subclinical mastitis. Vet. stn. 52, 445-460. 10.46419/ vs.52.4.12

19. LEE, M. R., W. H. SHENG, C. C. HUNG, C. J. YU, L. N. LEE and P. R. HSUEH (2015): Mycobacterium abscessus complex Infections in Humans. Emerg. Infect. Dis. 21, 1638-1646. 10.3201/2109.141634

20. MALIK, R. D. I. WIGNEY, D. DAWSON, P. MARTIN, G. B. HUNT and D. N. LOVE (2000): Infection of the subcutis and skin of cats with rapidly growing mycobacteria: a review of microbiological and clinical findings. J. Felin. Med. Surg. 2, 35-48. 10.1053/jfms.2000.0051

21. MIMOUNE, N., R. SAIDI, O. BENADJEL, D. KHELEF and R. KAIDI (2021): Alternative treatment of bovine mastitis. Vet. stn. 52, 639-649. 10.46419/vs.52.6.9

22. NASR ESFAHANI, B., H. R. YAZDI, S. MOGHIM, H. G. SAFAEI and H. ZARKESH ESFAHANI (2012): Rapid and accurate identification of Mycobacterium tuberculosis complex and common non-tuberculous mycobacteria by multiplex realtime PCR targeting different housekeeping genes. Curr. Microbiol. 65, 493-499. 10.1007/s00284-0120188-2

23. NOLAN, C. M., P. A. HASHISAKI and D. F. DUNDAS (1991): An out-break of soft-tissue infections due to Mycobacterium fortuitum associated with electromiyography. J. Infect. Dis. 163, 1150-1153. 10.1093/infdis/163.5.1150

24. RICHARDSON, A. (1970): Bovine mastitis associated with Mycobacterium smegmatis and an untypable Mycobacterium. Vet. Rec. 17, 497-498. 10.1136/vr.86.17.497

25. ROTMAN, D. A., A. BLAUVERT and F. A. KERDEL (1993): Widespread primary cutaneous infection with Mycobacterium fortuitum. Int. J. Dermatol. 32, 512-514. 10.1111/j.1365-4362.1993.tb02836.x
26. SAIDI, R., Z. CANTEKIN, N. MIMOUNE, Y. ERGUN, H. SOLMAZ, D. KHELEF and R. KAIDI (2021): Investigation of the presence of slime production, VanA gene and antiseptic resistance genes in Staphylococci isolated from bovine mastitis in Algeria. Vet. stn. 52, 57-63. 10.46419/vs.52.1.9

27. SCALLAN, E., R. M. HOEKSTRA, F. J. ANGULO, R. V. TAUXE, M. A. WIDDOWSON, S. L. ROY, J. L. JONES and P. M. GRIFFIN (2011): Foodborne Illness Acquired in the United States - Major Pathogens. Emerg. Infect. Dis. 17, 7-15. 10.3201/ eid1701.P11101

28. SCHULTZE, W. D. and W. B. BRASSO (1987): Characterization and identification of Mycobacterium smegmatis in bovine mastitis. Am. J. Vet. Res. 48, 739-742.

29. TALAAT, A. M., M. TRUCKSIS, A. S. KANE and R. REIMSCHUSSEL (1999): Pathogenicity of Mycobacterium fortuitum and Mycobacterium smegmatis to goldfish, Carassius auratus. Vet. Microbiol. 66, 151-164. 10.1016/S03781135(99)00002-4

30. TELENTI, A., F. MARCHESI, M. BALZ, F. BALLY, E. C. BÖTTGER and T. BODMER (1993): Rapid identification of mycobacteria to the species level by polymerase chain reaction and restriction enzyme analysis. J. Clin. Microbiol. 31, 175-178. 10.1128/ jcm.31.2.175-178.1993

31. THOMSON, J. R., N. MOLLISON and K. P. MATTHEWS (1988): An investigation of mastitis due to S. agalactiae, S. uberis, M. smegmatis in a herd. Vet. Rec. 122, 271-276. 10.1136/ vr.122.12.271

32. TURK, R., M. KOLEDIĆ, N. MAĆEŠIĆ, M. BENIĆ, V. DOBRANIĆ, D. ĐURIČIĆ, L. CVETNIĆ and M. SAMARDŽIJA (2017): The role of oxidative stress and inflammatory response in the pathogenesis of mastitis in dairy cows. Mljekarstvo 67, 91-101 10.15567/mljekarstvo.2017.0201

33. WALLACE, R. J., D. R. NASH, M. TSUKAMURA, Z. M. BLACKLOCK and V. A. SILCOX (1988): Human Disease Due to Mycobacterium smegmatis. J. Infect. Dis. 158, 52-59. 10.1093/infdis/158.1.52

34. WALLACE, R. J., J. M. MUSSER, S. I. HULL, V. A. SILCOX, L. C. STEELE, G. D. FORRESTER, A. LABIDI and R. K. SELADER (1989): Diversity and sources of rapidly growing mycobacteria associated with infections following cardiac surgery. J. Infect. Dis. 159, 708-716. 10.1093/infdis/159.4.708

35. WATTS, J. L. (1988): Etiological Agents of Bovine Mastitis. Vet. Microbiol. 16, 41-66. 10.1016/03781135(88)90126-5

36. WETZSTEIN, M. and J. GREENFIELD (1992): Mastitis caused by a Mycobacterium sp. Can. Vet. J., 33, 826 .

37. XU, Z., D. LU, X. ZHANG, H. LI, S. MENG, Y. S. PAN, A. S. BOYD, L. MA and Y. W. TANG (2013): Mycobacterium smegmatis in Skin Biopsy Specimens from Patients with Suppurative Granulomatous Inflammation. J. Clin. Microbiol. 3, 1028-1030. 10.1128/JCM.03421-12 


\section{Mastitis u krava prouzročen brzorastućim mikobakterijama iz okoliša}

Dr. sc. Luka CVETNIĆ, dr. med. vet., dr. sc. Silvio ŠPIČIĆ dr. med. vet., dr. sc. Gordan KOMPES, dr. med. vet., dr. sc. Boris Habrun, dr. med. vet., Hrvatski veterinarski institut Zagreb, Hrvatska; Vera KATALINIĆ-JANKOVIĆ, dr. med., Hrvatski zavod za javno zdravstvo, Hrvatska; Marija CVETNIĆ, dr. med. vet., Veterinarski fakultet Sveučilišta u Zagrebu, Zagreb, Hrvatska; dr. sc. Maja ZDELAR-TUK, dr. med. vet., dr. sc. Irena REIL, dr. med. vet., dr. sc. Sanja DUVNJAK, mag. ing. mol. biolog., Hrvatski veterinarski institut Zagreb, Hrvatska; Željko CVETNIĆ, dr. med. vet., akademik, Hrvatski veterinarski institut, Veterinarski zavod Križevci, Hrvatska; dr. sc. Miroslav BENIĆ, dr. med. vet., Hrvatski veterinarski institut, Zagreb, Hrvatska

Brzo-rastuće bakterije iz roda klaritromicinu. Gram-pozitivne acidoMycobacterium izdvojene se iz dva klinički rezistentne štapićaste bakterije uočili smo slična slučaja mastitisa krava $u$ relativno $u$ obojenim razmascima. Oba soja rasla su kratkom vremenu. Mikobakterije su izdvojene na krvnom agaru s dodatkom eskulina, obojene po Grammu i ZiehlNielsenu te im je provjerena sposobnost rasta pri $25{ }^{\circ} \mathrm{C}, 37^{\circ} \mathrm{C}$ i $42{ }^{\circ} \mathrm{C}$, korištenje željeza, sposobnost rasta na Löwenstein-Jensen agaru bez i s dodatkom $5 \% \mathrm{NaCl}$, tvorba arilsulfataze, sposobnost hidrolize tween 80 , redukcije telurita i tvorbe nitrat reduktaze i niacina. Molekularna identifikacija izolata provedena je korištenjem testova Mycobacteria GenoType CM i AS. Odsječci gena hsp65, rpoB, 16S rRNK te tzv. (engl. transcribed spacer sequence (ITS)) jednog izolata su sekvencirani. Osjetljivost izolata provjerili smo pomoću SENSITITRE RAPMYCOL ploča (TREK Diagnostic Systems Ltd.) prema trimetoprim/sulfametoksazolu, linezolidu, ciprofloksacinu, imipenemu, moksifloksacinu, cefepimu, cefoksitinu, amoksicilinu s klavulanskom kiselinom, amikacinu, ceftriaksonu, doksiciklinu, minociklinu, tigeciklinu, tobramicinu i pri temperaturama $25{ }^{\circ} \mathrm{C}, 37{ }^{\circ} \mathrm{C}$ i $42{ }^{\circ} \mathrm{C}$ te na podlozi LJ s i bez dodatka $5 \% \mathrm{NaCl}$. U oba soja utvrdili smo sposobnost korištenja željeza, tvorbe arilsulfataze, hidrolize Tween 80, redukcije telurita i tvorbe reduktaze nitrata. Sojevi nisu tvorili niacin. Oba izolata su testom GenoType Mycobacterium CM identificirana kao Mycobacterium fortuitum II/ Mycobacterium mageritense dok su GenoType Mycobacterium AS testom identificirana kao Mycobacterium smegmatis. Sekvencijskom analizom odsječka gena $16 \mathrm{~S}$ ribosomske RNK soja DS i usporedbom s javno dostupnim izolatima, utvrdili smo potpunu podudarnost sa sojem Mycobacterium smegmatis soj INHR2. Prema CLSI kriterijima, oba izolata su osjetljiva prema sulfametoksazolu s trimetoprimom, linezolidu, doksiciklinu, amikacinu i tobramicinu, a rezistentna prema klaritromicinu. Razlike između sojeva očitovale su se $u$ osjetljivosti prema cefoksitimu i tigeciklinu.

Ključne riječi: mikobakterije, mastitis, krava 